\title{
Methods for assessment of pre-harvest sprouting in wheat cultivars
}

\author{
Melícia Ingredi Araújo Gavazza(1), Manoel Carlos Bassoi(2), Tereza Cristina de Carvalho(1), \\ João Carlos Bespalhok Filho(1) and Maristela Panobianco(1)
}

\begin{abstract}
(1)Universidade Federal do Paraná, Departamento de Fitotecnia e Fitossanitarismo, Rua dos Funcionários, no 1.540, CEP 80035-050 Curitiba, PR, Brazil. E mail: melgavazza@hotmail.com, tcdcarva@gmail.com, bespa@ufpr.br, maristela@ufpr.br ${ }^{(2)}$ Embrapa Soja, Caixa Postal 1331, CEP 86100-000 Londrina, PR, Brazil. E mail: bassoi@cnpso.embrapa.br
\end{abstract}

\begin{abstract}
The objective of this work was to test methods for pre-harvest sprouting assessment in wheat cultivars. Fourteen wheat cultivars were grown in Londrina and Ponta Grossa municipalities, Paraná state, Brazil. They were sampled at 10 and 17 days after physiological maturity and evaluated using the methods of germination by rainfall simulation (in a greenhouse), in-ear grain sprouting, and grains removed from the ears. The in-ear grain sprouting method allowed the differentiation of cultivars, but showed different resistance levels from the available description of cultivars. The sprouting of grain removed from the ears did not allow a reliable distinction of data on germination in any harvest date or location. The method of rainfall simulation is the most suitable for the assessment of cultivars as to pre-harvest sprouting, regardless of the sampling date and evaluated location.
\end{abstract}

Index terms: Triticum aestivum, dormancy, grain quality, rainfall simulation.

\section{Métodos de avaliação da germinação na pré-colheita em cultivares de trigo}

\begin{abstract}
Resumo - O objetivo deste trabalho foi testar métodos para avaliação da germinação na pré-colheita de cultivares de trigo. Quatorze cultivares de trigo foram cultivadas em Londrina e Ponta Grossa, PR. Aos 10 e 17 dias após a maturidade fisiológica, elas foram colhidas e avaliadas pelos métodos de germinação por simulação de chuva (em casa de vegetação), com grãos nas espigas e com grãos removidos das espigas. O método do grão na espiga permitiu a diferenciação das cultivares, porém mostrou graus de resistência distintos das descrições disponíveis para as cultivares. O procedimento do grão removido da espiga não possibilitou a distinção segura dos dados obtidos quanto à germinação, em qualquer época ou local de coleta. O método por simulação de chuva é o mais adequado para avaliação de cultivares quanto à germinação na pré-colheita, independentemente da época de coleta e do local avaliado.
\end{abstract}

Termos para indexação: Triticum aestivum, dormência, qualidade do grão, simulação de chuva.

\section{Introduction}

The germination of wheat (Triticum aestivum L.) prior to harvest, known as pre-harvest sprouting, is considered one of the main reasons for the low quality of the grain (Andreoli et al., 2006). With the onset of germination, amylase activity in the endosperm becomes intense, causing the conversion of starch into sugar, resulting in quality damage, which reduces the producers' profit (Andreoli et al., 2006; Gerjets et al., 2010).

The problem of in-ear sprouting has been observed over many years and in several wheat-producing areas worldwide, representing a limiting factor of grain quality for the processing industry and for seed production. In this context, dormancy becomes interesting to minimize pre-harvest sprouting (Chen et al., 2008).
The areas most affected by this problem include northern and western Europe, northwestern United States, northern Australia, and the east of New Zealand, Canada, South Africa, Chile, Argentina, and Brazil. In Brazil, the north and west of Paraná, the south and southwest of São Paulo, and Mato Grosso do Sul state are the most affected areas, due to the rainfall frequency in the pre-harvest period (Reis \& Carvalho, 1989; Gerjets et al., 2010).

Several factors influence the process of in-ear sprouting, such as the dormancy period of cultivars (Biddulph et al., 2005) - caused by the presence of germination inhibitors, especially abscisic acid (ABA) (Hu et al., 2010) - and climatic factors, including the occurrence of high temperatures during grain ontogenesis, which reduces the dormancy period (Reis \& Carvalho, 1989; Nyachiro et al., 2002). 
Primary grain dormancy differ among wheat cultivars and can be genetically incorporated, expressing itself in the maturation stage (Chen et al., 2008), when the grains are still physiologically linked to the mother plant. This adaptive mechanism prevents grain germination while on the ear (Tavakkol-Afshari \& Hucl, 2002). It has high heritability in segregating populations ( $\mathrm{Gu}$ et al., 2010), due to recessive genes (Tavakkol-Afshari \& Hucl, 2002; Andreoli et al., 2006). This trait can be selected in breeding stages to prevent in-ear grain germination (Gu et al., 2010) and to develop cultivars with resistance to in-ear sprouting. Therefore, methods that assess dormancy in wheat grains may be useful in the selection of cultivars.

In this context, the falling number $(\mathrm{FN})$ procedure is used to determine the level of alpha-amylase activity in grains, based on the degree of viscosity of a gelatinized flour suspension. Similar methods are: amilography, determining the effect of viscosity of the alpha-amylase enzyme; and the rapid visco analyzer (RVA), also based on the ability of the same enzyme to liquefy a starch gel. Other methods used to determine germination capacity include grains removed from the ear (Andreoli et al., 2006) or the whole ear (McMaster \& Derera, 1976). Grain germination can also be measured by rainfall simulation, in ears previously removed from the mother plant (McMaster \& Derera, 1976). However, there are several restrictions to the use of these methods, such as: subjectivity of the results (Guarienti, 1996), long periods required for analysis of small-sized work samples, and need for specific equipment (Ross et al., 1987), which hamper the work of genetic improvement programs and increase the need for efficient procedures to evaluate dormancy.

The determination of in-ear sprouting by a practical procedure in cultivars of commercial interest is necessary and can contribute to wheat improvement programs. Moreover, the method for assessing susceptibility to in-ear sprouting should be tested in different environments, to study the cultivar vs. environment interaction. This would ensure the reliability of the test, taking into account the influence of environmental factors during grain maturation.

The objective of this work was to test methods for pre-harvest sprouting assessment in wheat cultivars at different locations.

\section{Materials and Methods}

The experiment was carried out in the winter season of 2008 in the experimental areas of Embrapa Soja, in the municipalities of Londrina $\left(23^{\circ} 11^{\prime} 33^{\prime \prime} \mathrm{S}\right.$ and $51^{\circ} 10^{\prime} 59^{\prime \prime} \mathrm{W}$, at $585 \mathrm{~m}$ altitude) and Ponta Grossa (25 $02^{\prime} 37^{\prime \prime} \mathrm{S}$ and $50^{\circ} 14^{\prime} 52^{\prime \prime} \mathrm{W}$, at 969 m altitude), Paraná state, Brazil, with $\mathrm{Cfa}$ and $\mathrm{Cfb}$ climate, respectively, according to Köppen-Geiger climate classification. Fourteen wheat cultivars tested by Embrapa Soja for their value for cultivation and use (VCU) in the state of Paraná were evaluated (Table 1). The cultivars were separated into groups according to the degree of resistance to in-ear sprouting and maturation, based on a description of cultivars proposed by Embrapa Trigo (Sistemas de produção, 2011).

The cultivars were sown in field plots, with one replicate per cultivar, at appropriate times for wheat sowing in Paraná state, namely May $5^{\text {th }}$ and July $10^{\text {th }}$, 2008, in Londrina and Ponta Grossa respectively. The plots consisted of two 2.0-m rows, spaced $0.2 \mathrm{~m}$ apart. In Londrina, the seeds were sown in a field area that can be completely covered with retractable roofs driven by an electrical device automatically triggered by the contact of water drops on the fiberglass roof -, after physiological grain maturity, in order to protect the material from undesired rain. In Ponta Grossa, the

Table 1. Resistance degree to pre-harvest sprouting in the ear, grade scale for assessment of resistance to pre-harvest sprouting, and maturation group of wheat cultivars evaluated in Londrina and Ponta Grossa.

\begin{tabular}{lccc}
\hline Cultivar & Resistance degree $^{(1)}$ & Maturation group & Grade scale \\
\hline BRS 18 & HS & Early & 6.0 \\
BRS Pardela & HS & Early & 6.0 \\
BRS 220 & HS & Medium & 6.0 \\
BRS Louro & S & Medium & 5.0 \\
CD 104 & S/MS & Medium & 4.5 \\
PF 014384 & MS & Medium & 4.0 \\
PF 014366 B & MS & Medium & 4.0 \\
Iapar 53 & MR & Medium & 3.0 \\
IPR 84 & MR & Medium & 3.0 \\
BRS Tangará & MR/R & Medium & 2.5 \\
SAFIRA & $\mathrm{R}$ & Medium & 2.0 \\
BRS 177 & $\mathrm{R}$ & Medium & 2.0 \\
WT 06121 & R/HR & Medium & 1.5 \\
Frontana & HR & Medium & 1.0 \\
\hline
\end{tabular}

(1)HS, highly susceptible; S, susceptible; MS, moderately susceptible; HR, highly resistant; R, resistant; MR, moderately resistant. 
seeds were sown in an open field, where the cultivars were exposed to the weather conditions.

Soil preparation, fertilization, pest and weed control were performed as recommended for wheat by Reunião da Comissão Brasileira de Pesquisa de Trigo e Triticale (2008).

To determine harvest time, morphological characteristics of plants were taken into account, such as color (transitional phase between green and yellow hue of the glumes and stalk of the wheat ear) and full grain maturity (stage 11), according to the phenological description of the scale of Feek \& Large, modified by Large (1954).

The ears were hand-harvested at 10 and 17 days after the point of physiological grain maturity. Each cultivar was separately harvested, sampling the ear from the main stem of each plant, totaling 62 ears per plot. The evaluation of the selection methods for cultivars resistant to in-ear sprouting was carried out at Embrapa Soja, in Londrina.

The germination test under rainfall simulation (McMaster \& Derera, 1976) was performed in four replicates of three ears per cultivar, totaling 12 ears per cultivar. The ears with part of the stalk were placed on polystyrene trays $(100 \times 50 \times 2.5 \mathrm{~cm})$, at $50 \mathrm{~cm}$ from the ground, in rows spaced $10 \mathrm{~cm}$ apart; the ears within each row were spaced at $5 \mathrm{~cm}$. Within regular intervals, mist was sprayed (flow of $3.5 \mathrm{~L} \mathrm{~h}^{-1}$ ) for $15 \mathrm{~min}$ and spraying was interrupted for $15 \mathrm{~min}$ (to raise grain moisture to $35 \%$ water). The trays were maintained in a greenhouse at controlled temperatures between 25 and $30^{\circ} \mathrm{C}$ for 60 hours. Then trays were transferred to a well-ventilated location, until the grains reached $13 \%$ water. The grains were threshed individually and analyzed by a stereoscopic microscope as to germination, based on the growth of the primary root (Bassoi, 2001). The results were expressed as mean germination percentage under rainfall simulation, per cultivar and municipality.

The test of grain germination in the ear was performed in four replicates of five ears per cultivar, totaling 20 ears per cultivar. The ears were soaked for $30 \mathrm{~s}$ in $600 \mathrm{~mL}$ of Priori Xtra (azoxystrobin + cyproconazole) at a concentration of $1.5 \mathrm{~mL}$ of the fungicide in 1,000 $\mathrm{mL}$ water and maintained on paper towels, in a ventilated location, for 24 hours. The ears were distributed on three sheets of paper towel, covered with three sheets of previously moistened paper towel (water amount of 2.5 times the dry paper weight), and placed in a germination chamber for six days, at $20^{\circ} \mathrm{C}$. After this period, to overcome seed dormancy, the rolls were stored in clear plastic bags and placed in an incubator, at $5^{\circ} \mathrm{C}$, for five days. Then, the rolls with ears were transferred to a germination chamber, at $20^{\circ} \mathrm{C}$, for three days. The ears were removed from the rolls and placed in a ventilated location for seven to ten days for manual grain threshing, in order to separate four 50 -seeds subsamples ( 200 seeds per cultivar). The grains were analyzed using a stereoscopic microscope to determine the appearance of primary roots and the germination percentage. Results were expressed as mean percentage of grain germination on the ear, according to the cultivar and municipalities.

The test with grains removed from the ears was also carried out for each cultivar. Twenty ears threshed by hand were divided into four replicates of 50 grains (200 seeds per cultivar). Then, the grains were immersed for $30 \mathrm{~s}$ in $600 \mathrm{~mL}$ Priori Xtra (azoxystrobin + cyproconazole) at a concentration of $1.5 \mathrm{~mL}$ of the fungicide in $1,000 \mathrm{~mL}$ water and placed on paper towels, in a ventilated location, for 24 hours. The grains were distributed on two sheets of paper towel and covered with two sheets of the same paper, previously moistened (water amount of 2.5 times the dry paper weight), and placed in a germination chamber, at $20^{\circ} \mathrm{C}$, for three days. Afterwards, the grains were analyzed under a stereoscopic microscope, based on the growth of the primary root. The non-germinated seeds were placed in an incubator, at $5^{\circ} \mathrm{C}$, for five days in order to break dormancy. The grains were placed again in the germination chamber on moistened paper for three days and reevaluated. The results were expressed as mean germination percentage of grains removed from the ear, according to the cultivar and municipalities.

Data from each test were analyzed in a completely randomized block design, for each location and sampling date, with four replicates. Means were compared by the Scott-Knott test, at $5 \%$ probability. For a more reliable assessment of the efficiency of the evaluated methods, a grade scale was created to score the resistance degree of cultivars to germination in the ear (Table 1). Based on this scale, the germination data obtained per method and the values assigned in the range of notes were correlated. The Spearman correlation coefficient between the rating scale and tested methods was also determined. 


\section{Results and Discussion}

The results of the rainfall simulation and the grain removed from the ear tests were better correlated with the grade scale than the grain germination on the ear test, at the sampling period of ten days after the grain physiological maturity (Table 2). This last test allowed the differentiation of cultivars, but showed different degrees of resistance than the expected according to the description of cultivars, as in the case of the cultivars BRS Pardela and BRS 220, which are considered sprouting susceptible (Sistemas de produção, 2011), but were identified as resistant to sprouting in the ear, mainly in Londrina.

When sampling was performed 17 days after physiological maturity, the methods generally allowed a clear separation of the cultivars, especially by the tests of rainfall simulation and grains on the ear, with higher correlations with the grade scale and, consequently, results closer to the genetic descriptions of the tested cultivars (Table 3 ).

The grain removed from the ear method did not allow a reliable distinction of cultivars as to the resistance degree to pre-harvest sprouting, according to the data on germination. For example, the cultivar
PF 014384 was classified as moderately susceptible by the genetic descriptor (Table 1), but was considered highly resistant in Ponta Grossa according to the grain removed from the ear method (Table 2). The correlation lack between the grade scale and this method can be attributed to dormancy loss of the grain and its total exposure to the ideal germination conditions when it is used. Moreover, the glumes are also removed from the spikelet, which can confer tolerance mechanisms to germination (Gatford et al., 2002). This can be explained by the fact that the glumes contain inhibitors or may constitute a physical barrier that prevents or hinders the entrance of water into the grain (Reis \& Carvalho, 1989; Manz et al., 2005).

Compared to the first sample (ten days, Table 2), the sampling 17 days after grain physiological maturity (Table 3) showed an average increase in germination, i.e., the cultivars remained longest under environmental conditions that favored a partial loss of grain dormancy. The loss of dormancy in the grains may have been favored by the greater exposure of the plant to high temperatures at field conditions, commonly observed at this time of the year. At high temperatures and with the absence of rain to imbibe the grains (Reis \& Carvalho, 1989), as is the case in northern Paraná State

Table 2. Mean germination values of the methods rainfall simulation (RS), grains in the ear (GE), and grains removed from the ears (GR), in the first sampling period (10 days after physiological maturity), in Londrina and Ponta Grossa ${ }^{(1)}$.

\begin{tabular}{|c|c|c|c|c|c|c|c|}
\hline \multirow[t]{3}{*}{ Cultivar } & \multirow[t]{3}{*}{ Resistance degree $^{(2)}$} & \multicolumn{3}{|c|}{ Londrina } & \multicolumn{3}{|c|}{ Ponta Grossa } \\
\hline & & $\mathrm{RS}$ & $\mathrm{GE}$ & GR & $\mathrm{RS}$ & GE & GR \\
\hline & & \multicolumn{3}{|c|}{--------------------' (\%) ---------------------- } & \multicolumn{3}{|c|}{--------------------- (\%) ------------------------- } \\
\hline BRS 18 & HS & $19 \mathrm{a}$ & $38 \mathrm{c}$ & $90 \mathrm{~b}$ & $36 \mathrm{c}$ & $34 \mathrm{a}$ & $63 b$ \\
\hline BRS Pardela & HS & $13 \mathrm{c}$ & $9 \mathrm{f}$ & $76 \mathrm{~d}$ & $44 \mathrm{a}$ & $36 \mathrm{a}$ & $69 b$ \\
\hline BRS 220 & HS & $9 \mathrm{e}$ & $9 f$ & $82 \mathrm{c}$ & $20 \mathrm{f}$ & $20 \mathrm{~d}$ & $51 \mathrm{c}$ \\
\hline BRS Louro & S & $16 b$ & $59 \mathrm{a}$ & $98 \mathrm{a}$ & $35 \mathrm{c}$ & $32 b$ & $78 \mathrm{a}$ \\
\hline CD 104 & $\mathrm{~S} / \mathrm{MS}$ & $12 \mathrm{~d}$ & $58 \mathrm{a}$ & $75 \mathrm{~d}$ & $22 \mathrm{e}$ & $31 \mathrm{~b}$ & $69 \mathrm{~b}$ \\
\hline PF 014384 & MS & $2 \mathrm{i}$ & $25 \mathrm{~d}$ & $73 b$ & $41 \mathrm{~b}$ & $13 \mathrm{f}$ & $28 \mathrm{e}$ \\
\hline PF 014366 B & MS & $5 \mathrm{~g}$ & $55 \mathrm{~b}$ & $81 \mathrm{c}$ & $9 \mathrm{~h}$ & $28 \mathrm{c}$ & $33 d$ \\
\hline Iapar 53 & MR & $2 \mathrm{i}$ & $11 \mathrm{e}$ & $60 \mathrm{e}$ & $13 \mathrm{~g}$ & $28 \mathrm{c}$ & $48 \mathrm{c}$ \\
\hline IPR 84 & MR & $1 \mathrm{j}$ & $8 \mathrm{f}$ & $66 \mathrm{e}$ & $13 \mathrm{~g}$ & $16 \mathrm{e}$ & $38 \mathrm{~d}$ \\
\hline BRS Tangará & $\mathrm{R} / \mathrm{MR}$ & $7 f$ & $7 \mathrm{f}$ & $63 \mathrm{e}$ & $29 \mathrm{~d}$ & $36 a$ & $74 \mathrm{a}$ \\
\hline SAFIRA & $\mathrm{R}$ & $3 \mathrm{~h}$ & $13 \mathrm{e}$ & $73 d$ & $4 j$ & $28 \mathrm{c}$ & $52 \mathrm{c}$ \\
\hline BRS 177 & $\mathrm{R}$ & $5 \mathrm{~g}$ & $8 \mathrm{f}$ & $45 f$ & $9 \mathrm{~h}$ & $13 \mathrm{f}$ & $25 \mathrm{e}$ \\
\hline WT 06121 & $\mathrm{HR} / \mathrm{R}$ & $1 \mathrm{j}$ & $3 g$ & $19 \mathrm{~g}$ & $7 \mathrm{i}$ & $14 \mathrm{f}$ & $8 \mathrm{f}$ \\
\hline Frontana & $\mathrm{HR}$ & $3 \mathrm{~h}$ & $1 \mathrm{~g}$ & $21 \mathrm{~g}$ & $3 \mathrm{j}$ & $11 \mathrm{f}$ & $16 f$ \\
\hline$\overline{\mathrm{CV}(\%)}$ & & 8.2 & 5.87 & 7.2 & 5.98 & 7.45 & 10.91 \\
\hline Correlation $^{(3)}$ & & 0.77 & 0.49 & 0.82 & 0.74 & 0.54 & 0.63 \\
\hline
\end{tabular}

${ }^{(1)}$ Means followed by equal letters, in the columns, do not differ by the Scott Knott test, at $5 \%$ probability. ${ }^{(2)} \mathrm{HS}$, highly susceptible; S, susceptible; MS, moderately susceptible; HR, highly resistant; R, resistant; MR, moderately resistant. ${ }^{(3)}$ Correlation between the grade scale (Table 1) and the evaluation methods. 
Table 3. Mean germination values of the methods rainfall simulation (RS), grains in the ear (GE), and rains removed from the ears (GR), in the second sampling period (17 days after physiological maturity), in Londrina and Ponta Grossa ${ }^{(1)}$.

\begin{tabular}{|c|c|c|c|c|c|c|c|}
\hline \multirow[t]{3}{*}{ Cultivar } & \multirow[t]{3}{*}{ Resistance degree ${ }^{(2)}$} & \multicolumn{3}{|c|}{ Londrina } & \multicolumn{3}{|c|}{ Ponta Grossa } \\
\hline & & $\mathrm{RS}$ & GE & GR & RS & GE & GR \\
\hline & & $----\cdot$ & $-(\%)$ & ------ & -----. & $(\%)-$ & ------ \\
\hline BRS 18 & HS & $24 \mathrm{e}$ & $90 a$ & $99 a$ & $73 b$ & $77 \mathrm{c}$ & $85 b$ \\
\hline BRS Pardela & HS & $44 a$ & $49 \mathrm{~d}$ & $97 \mathrm{a}$ & $53 \mathrm{~d}$ & $78 \mathrm{c}$ & $93 a$ \\
\hline BRS 220 & HS & $38 \mathrm{c}$ & $68 \mathrm{c}$ & $79 b$ & $78 \mathrm{a}$ & $83 b$ & $92 \mathrm{a}$ \\
\hline BRS Louro & S & $42 b$ & $86 \mathrm{~b}$ & $97 \mathrm{a}$ & $62 c$ & $91 \mathrm{a}$ & $94 \mathrm{a}$ \\
\hline CD 104 & $\mathrm{~S} / \mathrm{MS}$ & $27 d$ & $84 \mathrm{~b}$ & $94 \mathrm{a}$ & $53 \mathrm{~d}$ & $81 \mathrm{~b}$ & $98 \mathrm{a}$ \\
\hline PF 014384 & MS & $28 \mathrm{~d}$ & $37 \mathrm{e}$ & $80 \mathrm{~b}$ & $42 \mathrm{e}$ & $50 \mathrm{f}$ & $19 \mathrm{c}$ \\
\hline PF 014366 B & MS & $18 \mathrm{f}$ & $89 \mathrm{a}$ & $84 b$ & $23 \mathrm{f}$ & $84 \mathrm{~b}$ & $93 \mathrm{a}$ \\
\hline Iapar 53 & MR & $7 \mathrm{i}$ & $10 \mathrm{~h}$ & $35 \mathrm{~d}$ & $23 \mathrm{f}$ & $26 \mathrm{i}$ & $90 \mathrm{~b}$ \\
\hline IPR 84 & MR & $12 \mathrm{~g}$ & $13 \mathrm{~h}$ & $83 b$ & $19 \mathrm{~g}$ & $53 \mathrm{e}$ & $98 \mathrm{a}$ \\
\hline BRS Tangará & $\mathrm{R} / \mathrm{MR}$ & $17 \mathrm{f}$ & $31 \mathrm{f}$ & $81 \mathrm{~b}$ & $40 \mathrm{e}$ & $56 \mathrm{~d}$ & $98 \mathrm{a}$ \\
\hline SAFIRA & $\mathrm{R}$ & $8 \mathrm{~h}$ & $28 \mathrm{f}$ & $68 \mathrm{c}$ & $5 \mathrm{j}$ & $18 \mathrm{j}$ & $89 b$ \\
\hline BRS 177 & $\mathrm{R}$ & $18 \mathrm{f}$ & $20 \mathrm{~g}$ & $92 \mathrm{a}$ & $12 \mathrm{i}$ & $45 \mathrm{~g}$ & $84 b$ \\
\hline WT 06121 & $\mathrm{HR} / \mathrm{R}$ & $23 \mathrm{e}$ & $1 \mathrm{i}$ & $72 \mathrm{c}$ & $18 \mathrm{~g}$ & $34 \mathrm{~h}$ & $98 \mathrm{a}$ \\
\hline Frontana & HR & $6 \mathrm{i}$ & $3 \mathrm{i}$ & $23 \mathrm{e}$ & $16 \mathrm{~h}$ & 121 & $19 \mathrm{c}$ \\
\hline CV (\%) & & 3.82 & 5.14 & 5.76 & 3.67 & 2.88 & 6.82 \\
\hline Correlation ${ }^{(3)}$ & & 0.75 & 0.72 & 0.61 & 0.89 & 0.85 & 0.25 \\
\hline Correlation $^{(4)}$ & & $0.60 * *$ & $0.83 *$ & $0.15^{\mathrm{ns}}$ & $0.80^{*}$ & $0.51^{\mathrm{ns}}$ & $0.11^{\text {ns }}$ \\
\hline
\end{tabular}

${ }^{(1)}$ Means followed by equal letters, in the columns, do not differ by the Scott Knott test, at $5 \%$ probability. ${ }^{(2)} \mathrm{HS}$, highly susceptible; S, susceptible; MS, moderately susceptible; HR, highly resistant; R, resistant; MR, moderately resistant. ${ }^{(3)}$ Correlation between the grade scale (Table 1) and the evaluation

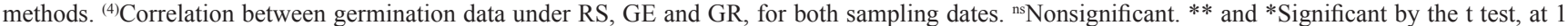
and $5 \%$ probability, respectively.

(in the second fortnight of August) and Ponta Grossa (in November), dormancy is usually broken. However, lower temperatures associated with high humidity can also break grain dormancy (Ueno, 2002; Finch-Savage et al., 2007).

The results from rainfall simulation method were significantly correlated between the sampling dates in both tested locations (Table 3), which indicated that the material could be collected regardless of the harvest date and evaluated location. Furthermore, this test is not only simpler, but better suited for the selection of cultivars for in-ear sprouting. Among the wetting treatments described in the literature, rain simulators have been used to control temperature, relative humidity, and spike wetting in the post-physiological maturity period, providing a more accurate assessment of genetic variation for pre-harvest sprouting tolerance (Trethowan, 1995).

In the test of sprouted grains on the ear, there was a significant correlation between the two periods only in Londrina (Table 3). For the method of grain removed from the ear, no significant correlation was observed between the periods in any location, confirming the results of Franco et al. (2009).
Efficient methods contributing to the selection of cultivars with resistance to sprouting in the ear may be useful in breeding programs, allowing the transfer of the dormancy trait to new cultivars. This property is advantageous for wheat, since precocious sprouting affects the quality of the grain produced, as well as the physiological potential of seeds destined for sowing.

\section{Conclusion}

The method of rainfall simulation is the most suitable for the assessment of cultivars as to pre-harvest sprouting, regardless of the sampling date and evaluated location.

\section{References}

ANDREOLI, C.; BASSOI, M.C.; BRUNETTA, D. Genetic control of seed dormancy and pre-harvest sprouting in wheat. Scientia Agricola, v.63, p.564-566, 2006.

BASSOI, M.C. Quantitative trait analysis of grain dormancy in wheat (Triticum aestivum L. Thell). 2001. 240p. Thesis (PhD) University of East Anglia, Norwich.

BIDDULPH, T.B.; MARES, D.J.; PLUMMER, J.A.; SETTER, T.L. Drought and high temperature increases preharvest sprouting 
tolerance in a genotype without grain dormancy. Euphytica, v.143, p.277-283, 2005.

CHEN, C.-X.; CAI, S.-B.; BAI, G.-H. A major QTL controlling seed dormancy and pre-harvest sprouting resistance on chromosome $4 \mathrm{~A}$ in a Chinese wheat landrace. Molecular Breeding, v.21, p.351-358, 2008 .

FINCH-SAVAGE, W.E.; CADMAN, C.S.C.; TOOROP, P.E.; LYNN, J.R.; HILHORST, H.W.M. Seed dormancy release in Arabidopsis Cvi by dry after-ripening, low temperature, nitrate and light shows common quantitative patterns of gene expression directed by environmentally specific sensing. Plant Journal, v.51, p.60-78, 2007.

FRANCO, F.A.; PINTO, R.J.B.; SCAPIM, C.A.; SCHUSTER, I.; VIGANO, J.; MARCHIORO, V.S.; BRACCINI, A.L. Pré-esfriamento para superação da dormência de sementes de trigo colhidas na época da maturidade. Revista Brasileira de Sementes, v.31, p.245-252, 2009.

GATFORD, K.T.; EASTWOOD, R.F.; HALLORAN, G.M. Germination inhibitors in bracts surrounding the grain of Triticum tauschii. Functional Plant Biology, v.29, p.881-890, 2002.

GERJETS, T.; SCHOLEFIELD, D.; FOULKES, M.J.; LENTON, J.R.; HOLDSWORTH, M.J. An analysis of dormancy, ABA responsiveness, after-ripening and pre-harvest sprouting in hexaploid wheat (Triticum aestivum L.) caryopses. Journal of Experimental Botany, v.61, p.597-607, 2010.

GU, X.-Y.; ZHANG, L.; GLOVER, K.D.; CHU, C.; XU, S.S.; FARIS, J.D.; FRIESEN, T.L.; IBRAHIM, A. Genetic variation of seed dormancy in synthetic hexaploid wheat-derived populations. Crop Science, v.50, p.1318-1324, 2010.

GUARIENTI, E.M. Qualidade industrial de trigo. Passo Fundo: Embrapa-CNPT, 1996. 36p. (EMBRAPA-CNPT. Documentos, 27).

HU, B.; WAN, X.-R.; LIU, X.-H.; GUO, D.; LI, L. Abscisic acid (ABA)-mediated inhibition of seed germination involves a positive feedback regulation of ABA biosynthesis in Arachis hypogaea L. African Journal of Biotechnology, v.9, p.1578-1586, 2010.

LARGE, E.C. Growth stages in cereals: illustration of the Feekes scale. Plant Pathology, v.3, p.128-129, 1954.
MANZ, B.; MÜLlER, K.; KUCERA, B.; VOLKE, F.; LEUBNER-METZGER, G. Water uptake and distribution in germinating tobacco seeds investigated in vivo by nuclear magnetic resonance imaging. Plant Physiology, v.138, p.1538-1551, 2005.

MCMASTER, C.J.; DERERA, N.F. Methodology and sample preparation when screening for sprouting damage in cereals. Cereal Research Communication, v.4, p.251-254, 1976.

NYACHIRO, J.M.; CLARKE, F.R.; DEPAUW, R.M.; KNOX, R.E.; ARMSTRONG, K.C. Temperature effects on seed germination and expression of seed dormancy in wheat. Euphytica, v.126, p.123-127, 2002.

REIS, M.S. dos; CARVALHO, F.I.F. de. Eficiência de três métodos artificiais para identificação da variabilidade do caráter germinação na espiga em trigo. Revista Brasileira de Fisiologia Vegetal, v.1, p.63-72, 1989.

REUNIÃO DA COMISSÃO BRASILEIRA DE PESQUISA DE TRIGO E TRITICALE, 2., 2008, Passo Fundo. Informações técnicas para a safra 2009: trigo e triticale. Passo Fundo, RS: Embrapa Trigo, 2008. 172p.

ROSS, A.S.; WALKER, C.E.; BOOTH, R.I.; ORTH, R.A.; WRIGLEY, C.W. The rapid visco-analyzer: a new technique for the estimation of sprout damage. Cereal Foods World, v.32, p.827-829, 1987.

SISTEMAS de produção: cultivares de trigo. Disponível em: $<$ http://www.cnpt.embrapa.br/culturas/trigo/cultivares/index.htm>. Acesso em: 21 abr. 2011.

TAVAKKOL-AFSHARI, R.; HUCL, P. Variation of seed dormancy and after-ripening in tetraploid wheat (Triticum durum, T. turgidum, T. turanicum, T. carthlicum, T. polonicum). Journal of Agricultural Science and Technology, v.4, p.23-36, 2002.

TRETHOWAN, R.M. Evaluation and selection of bread wheat (Triticum aestivum L.) for preharvest sprouting tolerance. Australian Journal of Agricultural Research, v.46, p.463-474, 1995.

UENO, K. Effects of desiccation and a change in temperature on germination of immature grains of wheat (Triticum aestivum L.). Euphytica, v.126, p.107-113, 2002.

$\overline{\text { Received on March 2, } 2012 \text { and accepted on June 15, } 2012}$ 